\title{
Ultra-Low Carbon Technologies for Building Retrofits
}

\author{
Samantha Lane ${ }^{1}$, Andrea Frisque ${ }^{2}$, Jeanie Chan ${ }^{2}$, Randy Irwin ${ }^{3}$ \\ ${ }^{1}$ Stantec Consulting Ltd., Calgary, Canada \\ ${ }^{2}$ Stantec Consulting Ltd., Vancouver, Canada \\ ${ }^{3}$ Stantec Consulting Ltd., Victoria, Canada
}

\begin{abstract}
Reaching the goal of net-zero carbon consumption is particularly challenging for existing buildings. Calibrated energy simulations, using IES VE and EnergyPlus, of a portfolio of ten existing commercial buildings in Canada were used to develop paths to net zero carbon. Emerging technologies including carbon sequestration, algae farming, electrochromic glass, predictive controls, building integrated photovoltaic, and fuel cell technologies were evaluated for their applicability in today's built environment. This paper provides recommendations and commentary on the available information, relative impact and economic feasibility of innovative and new but proven technologies for evaluation in existing building retrofit simulations

This research paper is highly relevant to building owners, and simulation specialists given that in $2030,75 \%$ of our building stock will consist of buildings in existence today (ECCC, 2016), while net zero carbon strategies typically focus on new construction methodologies. Expertise in recommending and analysing improvement measures for existing buildings represents an exciting and growing opportunity for building simulation specialists. This paper provides detailed and tested recommendations on the relative utility of emerging technologies for achieving net-zero carbon and provides comment on the relative percentage of retrofit budget that was diverted to innovative and emerging technologies to simulate maximum potential site carbon reduction.
\end{abstract}

\section{Introduction}

The Government of Canada issued as a federal priority to significantly reduce greenhouse gas (GHG) emissions in the country by 2030 , as published in the Pan-Canadian Framework on Clean Growth and Climate Change (ECCC, 2016), to assist in achieving Canada's commitments under the 2015 Paris Agreement. The document specifically references the importance of retrofitting existing building stock to improve energy performance and reduce the associated operating emissions.

This paper outlines the results of in-depth energy simulation investigations of design strategies that substantially reduce the GHG emissions associated with operating a portfolio of ten existing facilities across Canada. The portfolio owner specified a primary aim of achieving carbon neutral operations, with secondary aims of realizing a positive return on investment (ROI) with a positive Net Present Value (NPV).

\section{Portfolio Characteristics}

Table 1 below summarizes the location in Canada and gross floor area of each existing building.

Table 1: Summary of Projects Analysed.

\begin{tabular}{|c|c|c|}
\hline $\begin{array}{c}\text { Building } \\
\text { Number }\end{array}$ & City, Province & $\begin{array}{c}\text { Gross Modelled } \\
\text { Floor Area } \\
\text { m2 }\end{array}$ \\
\hline 1 & St. John, NB & 12,730 \\
\hline 2 & Shediac, NB & 7,553 \\
\hline 3 & Sydney, NS & 7,170 \\
\hline 4 & Moncton, NB & 13,318 \\
\hline 5 & St. John's, NL & 12,484 \\
\hline 6 & Bathurst, NB & 12,273 \\
\hline 7 & Amherst, NS & 4,697 \\
\hline 8 & Sudbury, ON & 39,156 \\
\hline 9 & Ottawa, ON & 47,691 \\
\hline 10 & Edmonton, AB & 19,739 \\
\hline
\end{tabular}

The data in Table 1 demonstrates that each building can be described as commercial office buildings, all over the BOMA Canada (2019) definition of Office Building with floor area greater than 5,000 square feet $\left(465 \mathrm{~m}^{2}\right)$. Each building is also located in a heating-dominant climate. The existing buildings investigated reside in ASHRAE climate zones 6-7, with heating degree days below $18^{\circ} \mathrm{C}$ ranging from $4500-5120$.

Table 2 below outlines the emission intensity of the local electrical grid for each project at the time of the study, obtained from the National Inventory Report (ECCC, 2018)

Table 2: Summary of Projects Analysed.

\begin{tabular}{|c|c|c|}
\hline $\begin{array}{c}\text { Building } \\
\text { Number }\end{array}$ & Location & $\begin{array}{c}\text { GHG intensity of } \\
\text { Electric Grid } \\
\text { [gCO2eq } / \mathbf{k W h} \text { ] }\end{array}$ \\
\hline 1 & St. John, NB & 280 \\
\hline 2 & Shediac, NB & 280 \\
\hline 3 & Sydney, NS & 600 \\
\hline 4 & Moncton, NB & 181 \\
\hline 5 & St. John's, NL & 32 \\
\hline 6 & Bathurst, NB & 280 \\
\hline 7 & Amherst, NS & 600 \\
\hline 8 & Sudbury, ON & 40 \\
\hline 9 & Ottawa, ON & 40 \\
\hline 10 & Edmonton, AB & 760 \\
\hline
\end{tabular}


The data in Table 2 indicates that greenhouse gas emission intensity of the available electricity grid varies widely between locations. The intensity of the local grid relative to the intensity of alternative fuel options available (natural gas, propane, heating oil, district energy, etc.) will determine whether electrification or fuel switching is a viable retrofit option for carbon emissions reductions.

\section{Challenges for Existing Building Carbon Retrofits}

The following challenges of achieving large carbon savings in existing buildings were identified as significant during the study.

\section{Energy Sources and GHG Emission Intensity}

The emissions generated as part of normal building operations are dependent on the amount of energy consumed, but also largely on the greenhouse has emission intensity of the feed fuel. For example, in locations with low-intensity electrical grids, converting the fossil-fuel heating systems to electric-fuelled systems will result in drastic improvements to efficiency. However, in locations with high electrical grid emission intensities, the same retrofit would result in increased carbon emissions.

In locations with relatively high electrical grid emission intensities, the largest opportunities for carbon savings come not from fuel-switching retrofits but instead from those focused on reducing energy consumption. This is achieved either through reduced demand on or improved efficiency of energy consuming systems.

The emission intensity factor and available energy sources must be considered when analysing potential retrofit options. These factors are typically beyond the control of the building owner and can complicate the retrofit strategy.

Another important factor related to grid carbon intensity is their dynamic nature. The grid intensity at the time of a carbon reduction feasibility study or retrofit is not necessarily indicative of the future carbon intensity. This can create uncertainty for building owners looking to invest capital to see long-term carbon reductions.

\section{Envelope Economics}

Successfully reducing carbon emissions associated with building operations is typically achieved through the reduction of building energy consumption. In a heating dominated climate, improvements to the thermal performance of building envelope elements can be a key factor to reducing energy demand. Building envelope elements include walls, roofs, windows, doors, and below-ground insulation.

Upgrades to building envelopes tend to be relatively costly. This is due to their size, impact on architectural and structural systems, and product availability. New construction buildings often struggle to see a reasonable simple payback period on building envelope upgrades and this issue is even more pronounced in existing buildings. Upgrades to existing envelope systems can necessitate changes to the structural and architectural systems. Depending on existing systems, this can also mean a costly demolition period with significant disruption to building occupants. For these reasons, envelope upgrades are often undesired and economically unattractive, despite their potential benefit to carbon reductions.

\section{Other Challenges}

A Roadmap for Retrofits in Canada (Canada Green Building Council, 2017), lists the following additional challenges to existing building carbon retrofits:

- Building size: buildings over $50,000 \mathrm{ft}^{2}\left(4,645 \mathrm{~m}^{2}\right)$ offer less relative potential for carbon reductions due to system size and operations

- Building age: Older buildings will reflect more outdated building codes which may not have included energy efficiency requirements

- Building type: building typologies with process requirements or extended operating hours are more likely to emit more carbon as part of operations

\section{Calibration Methodology}

The simulated buildings in this study did not have available metering infrastructure or detailed sub-metering data, a commonly encountered difficulty with simulating existing buildings. The ASHRAE Guideline 14 (2014) provides methods to relate measured energy use to historical weather conditions and provides tools to characterize load shapes and account for diversity in occupant-based energy uses. The guideline also presents acceptable calibration tolerances based on the type of data that is available. ASHRAE Guideline 14 was followed to acceptably simulate the end uses of the studied buildings, given only the annual billed utility data.

The simulation inputs are listed, separated into static and dynamic elements. Across the portfolio of buildings, these were modelled using both the IES VE and EnergyPlus simulation software.

\section{Static Elements}

- Building geometry: As built drawings

- Envelope performance: As built drawings and site review

- Interior lighting power: Detailed as built take off and site review

- Exterior lighting power: Existing building documentation and site review

- Interior equipment loads: calculated based on occupancy density and on-site equipment review

- Service hot water: Based on occupants and installed fixtures

- Interior process loads (data rooms, kitchens, laboratories): As-builts and site review

- Mechanical systems: As-builts, site review, building operator interviews, and control system review

\section{Dynamic Elements}

- Weather File

- Schedules

- Interior Lighting

- Interior Equipment (plugs) 
- Occupants

- Exterior lights

- Elevators

- Service hot water

- HVAC systems heating and cooling set points

- HVAC system schedule

- Infiltration schedule

\section{Calibration Acceptance Criteria}

The acceptable level of correlation, in ASHRAE Guideline 14, between the measured energy use and the modelled is expressed as a function of the type of data available. A calibration result based on monthly data needs to be more closely matched to the measured energy use than an hourly based comparison to be considered acceptable. The calibration results are evaluated using the statistical metrics Mean Bias Error (MBE) and the Coefficient of Variation of the of mean square error (CvRMSE).

The mean bias error is calculated by subtracting the simulated energy consumption from the measured consumption for all intervals over a given time period. The differences from each time period are summed and divided by the sum of the measured consumption over the same time period. MBE calculation is expressed in Equation 1.

$$
\operatorname{MBE}(\%)=\frac{\sum_{\text {Period }}(S-M)}{\sum_{\text {Period }} M} X 100
$$

Where:

$\mathrm{M}$ is the measured fuel consumption during the interval $\mathrm{S}$ is the simulated fuel consumption during the interval

The $\mathrm{Cv}(\mathrm{RMSE})$ is a normalized measure of the variability between two sets of data. For calibrated simulation purposes, it is obtained by squaring the difference between paired data points, summing the squared differences over each interval through the period, and then dividing by the number of points, which yields the mean squared error. The square root of this quantity yields the RMSE. The $\mathrm{Cv}(\mathrm{RMSE})$, is obtained by dividing the RMSE by the mean of the measured data for the period. The RMSE for the period is calculated using Equation 2.

$$
\text { RMSEperiod }=\sqrt{\sum \frac{(S-M)^{2}}{N}}
$$

Where:

$\mathrm{N}$ are the number of time intervals in the monitoring period

The mean of the measured data for the period is calculated using Equation 3.

$$
\text { Aperiod }=\frac{\sum_{\text {Period } M}}{N}
$$

The $\mathrm{Cv}(\mathrm{RSME})$ is calculated using Equation 4.

$$
C v(\text { RMSEperiod })=\frac{\text { RMSEperiod }}{\text { Aperiod }} \times 100
$$

The acceptable calibration tolerances according to ASHRAE Guideline 14 is listed in Table 3.
Table 3: Acceptable Calibration Tolerances*.

\begin{tabular}{|c|c|c|}
\hline $\begin{array}{c}\text { Calibration } \\
\text { Type }\end{array}$ & Index & $\begin{array}{c}\text { Acceptable } \\
\text { Value }\end{array}$ \\
\hline Monthly & MBEmonth & $\pm 5 \%$ \\
& Cv(RSMEmonth) & $15 \%$ \\
\hline Hourly & MBEmonth & $\pm 10 \%$ \\
& & $30 \%$ \\
\hline
\end{tabular}

* Data in this table is taken from Guideline 14-2014, Section 5.3.3.3.10

The calibration procedure is iterative where model inputs are adjusted, and results are compared to the measured energy use. Inputs are adjusted systematically until the model achieves an acceptable calibration tolerance. The calibration procedure continues until the calibration accuracy threshold is achieved. Table 4 below lists the results of this calibration, as reported by MBE and CvRSME values.

Table 4: Summary of Monthly Calibration Results.

\begin{tabular}{|c|c|c|c|}
\hline $\begin{array}{c}\text { Building } \\
\text { Number }\end{array}$ & MBE & CvRSME & $\begin{array}{c}\text { Meets ASHRAE } \\
\text { Guideline 14 } \\
\text { Criteria? }\end{array}$ \\
\hline 1 & $-2.8 \%$ & $7.3 \%$ & Yes \\
\hline 2 & $-1.5 \%$ & $7.5 \%$ & Yes \\
\hline 3 & $0.9 \%$ & $4.0 \%$ & Yes \\
\hline 4 & $-2.4 \%$ & $8.0 \%$ & Yes \\
\hline 5 & $-0.5 \%$ & $6.1 \%$ & Yes \\
\hline 6 & $3.0 \%$ & $8.6 \%$ & Yes \\
\hline 7 & $-3.8 \%$ & $14.0 \%$ & Yes \\
\hline 8 & $1.0 \%$ & $15.0 \%$ & Yes \\
\hline 9 & $1.0 \%$ & $10.0 \%$ & Yes \\
\hline 10 & $-0.4 \%$ & $10.1 \%$ & Yes \\
\hline
\end{tabular}

\section{Conventional Measures for Existing Building Carbon Retrofits}

Once calibrated, a variety of emission reduction measures (ERMs) were investigated for each project to determine the ideal bundle to maximize carbon emission reductions and study their associated energy savings. These measures can be grouped into six categories as follows:

1. Envelope Improvements

2. Heating and Cooling Improvements

3. Ventilation System Improvements

4. Controls and Operational Improvements

5. Electrical and Lighting Improvements

The list of ERMs tested in each category was generated by observing the simulated energy end uses for each building and providing viable retrofit options for the relevant systems which could improve performance in existing energy end uses.

\section{Building Envelope Improvements}

In this context, the building envelope is defined as the physical components which separate the conditioned building space from the exterior envelopment. Retrofits to the building envelope can either improve thermal performance or air tightness. The investigated ERMs included improvements to the following envelope systems: roofs, walls, windows, doors, air tightness, and underground insulation. 
Roof improvements typically involve removing the existing assembly down to substrate and installing a new insulated roofing system complete with all new flashing and associated curb/parapet upgrades. The roof improvement ERMs included in this study range from the addition of R-40 to R-97.

Wall improvements can also be measured in thermal resistance (units), however the suitable retrofit options to improve thermal performance will vary depending on the existing wall and structural systems. Several of the investigated buildings are classified as Heritage Status, further limiting the available methods of improving the exterior wall thermal performance.

Window improvements are conventionally measured by their ability to reduce the thermal conductivity of the window unit (the inverse of thermal resistance). This can include improvements to their glazing and/or framing systems.

The thermal performance of door systems is improved by removing existing doors and replacing them with thermally broken and insulated products.

Retrofits of roof, wall, window, and door systems can be designed to improve air tightness of the building envelope. This reduces air infiltration and exfiltration, resulting in a lower demand on building conditioning systems.

Underground insulation along foundation walls and under floor slabs can reduce thermal bridging and thus heat loss. These are often disregarded in existing building retrofits as the underground components are typically difficult to access once the building has been constructed. This study included the investigation of underground insulation measures.

\section{Heating and Cooling System Improvements}

All simulated buildings included systems designed to thermally condition the interior space. Even in cold climates 6-8, cooling is often necessary to temper outside air during warm seasons or interior air in conditions with high internal gains.

Heating and cooling system improvements analysed included:

- Natural gas boiler upgrades, both condensing $(89 \%+$ efficient) and near-condensing (86-89\% efficient)

- Upgrades to electric boilers (100\% efficient)

- Ground source heat pump systems (COP 3.0+)

- Distributed heat pumps

- Chiller upgrades, including absorption, screw, and magnetic bearing technologies

\section{Ventilation System Improvements}

In cold climates, for much of the year energy is spent on warming incoming fresh air for distribution to occupants. In the referenced jurisdictions, all new buildings must condition to various versions of ASHRAE 62.1 Ventilation for Acceptable Indoor Air Quality (ASHRAE, 2013). Some/all of the buildings studied were overventilating due to poor controls, wrong-sized capacities, operational ease, or system limitations. In the sample set, the following ventilation system ERMs were simulated to evaluate their relative impact on performance:

- Changing equipment capacity to provide adequate outside air without overventilating

- Changing equipment function to enable flexible ventilation for zones with varied occupancy

- Addition of ventilation control logic such as demand controlled ventilation (DCV), free cooling, and night set-back

- Addition of heat recovery technology to pre-heat incoming ventilation air with exhaust conditioned air

\section{Controls and Operational Improvements}

Modern buildings are typically controlled by a building automation system (BAS) which uses sensors and schedules to efficiently operate building systems. A properly designed, installed, and commissioned BAS system improves comfort, reduces energy use and operating costs, and allows operators to perform continuing improvements of comfort and energy performance. Depending on vintage, existing buildings can have no BAS system, an outdated BAS system, or multiple BAS systems which may compete with one another or not properly interface.

Controls and operational retrofits for carbon reductions can include:

- Addition of BAS system

- Proper commissioning of BAS system to operate systems with efficient logic, for example schedule heat pumps before electric baseboards

- Reset logic for supply air temperature, chilled water, hot water, and air static pressure

\section{Electrical and Lighting System Improvements}

When improving the efficiency of electrical and lighting systems, it is important to account for the associated impact on interal gains seen by the space. In cold climates, a reduction to electrical demand often results in an associated increase to heating demand. The effect on internal gains was included in the study.

In the study, the following electrical and lighting system improvements were simulated to evaluate their relative impact on performance:

- Reduction in lighting power density

- Retrofit of elevator systems to include regenerative drive technology

\section{Emerging and Innovative Technologies for Existing Building Carbon Retrofits}

To reach the ambitious goal of carbon neutrality, the recommended bundle of emission reduction measures required more than typical retrofit measures. The following emerging and innovative technologies were recommended in the studies, following detailed simulation and financial analysis.

\section{Rooftop Solar Photovoltaic}

The integration of rooftop photovoltaic technology (PV) can offset both the energy and carbon used onsite. The PV panels convert sunlight (photons) directly into electricity 
(voltage), which is referred to as the PV effect. Solar cells produce direct current electricity from sunlight which can be used to power equipment in real-time or to recharge a battery, in which case the energy can be stored for later use. Onsite PV panels can also be connected to the grid to contribute to the energy generation.

There are several types of PV panels, including mono- and polycrystalline, thin film, string ribbon, amorphous silicon, cadmium telluride, copper indium gallium selenide solar cells and building-integrated PV. Each type of solar cell has its advantages and disadvantages, which entail ranges of efficiency, efficiency of output per panel area, cost, waste produced during manufacturing process etc. The chosen PV technology is polycrystalline silicone, which may not offer the highest efficiency, but is considered amongst the more cost-effective solutions. Newer generation polycrystalline solar cells now have typical efficiencies is in the range of $13 \%$ to $22 \%$.

\section{Ground-Mounted Solar Photovoltaic}

Similar to the technology used for roof-mounted solar PV, ground-mounted solar PV can be used to offset energy and carbon. These were simulated on all ten projects in the study. Panels can be mounted to stand-alone structures, or over existing parking lots. In the latter case, they have the added benefit of shading cars from snow and sunlight. Whether a retrofit project should consider ground-mounted solar PV is largely a factor of available space for panels. Simulations can be carried out to determine optimal PV area, row spacing, angle of inclination, cell temperature, and panel efficiency vs. cost.

\section{Small Scale Tidal Turbine}

The addition of a small-scale tidal turbine was recommended in one project to reach its maximum site carbon reduction potential. The building is located in close proximity to a harbour, which experiences significant tidal conditions, creating the ideal environment for renewable energy harnessed in the form of tidal turbines. While technically feasible, initial investment for small scale tidal turbine systems are quite high. In the simulated project, the capital required for the small-scale tidal turbine represented $41 \%$ of the overall carbon retrofit budget.

\section{Battery Systems for Off Grid Storage}

Battery storage systems offset electrical peaks, reducing demand as seen by the electrical grid. They can be particularly beneficial when paired with solar PV systems in cases where the solar load shape does not match the building usage profile. Electrical utility companies in some areas set a net-metering limit on how much renewable electricity can be injected into the grid when a building's production exceeds consumption. Battery storage allows retrofit projects to size solar PV systems to their available space or demand instead of the limit imposed by the utility.

Battery storage systems were recommended in nine of the ten projects. In each case, they were used as a strategy to overcome net-metering limits set by the local utility. Building performance analysts must consider whether the existing building area can accommodate a battery storage system when recommending solar PV systems.

\section{Ground Source Heat Exchange Systems}

Ground source heat pump (GSHP) systems use the earth's mass as a thermal reservoir, a heat sink during the summer and as a heat source during the winter. GHSP systems are generally more efficient than conventional heating systems and some cooling systems, although not as efficient in the best variable speed centrifugal chillers.

A GSHP system is comprised of three major components: a heat pump, an earth connection system, and an interior heating and cooling distribution system. The heat pump transfers the energy between the heating and cooling distribution system to the earth connection system, through which the refrigerant in the core of the heat pump loop undergoes the vapour compression refrigeration cycle.

Based on modelling, the GSHP systems resulted in considerable energy and GHG emission savings. The GSHP system was recommended on eight of the ten simulated buildings in order to reach their maximum site potential for carbon reduction. It should be noted that the low-temperature system can only be recommended in a building with a well-sealed and insulated building envelope. In most cases, this ERM was paired with significant envelope upgrades.

\section{Solar Air Heater}

The addition of a solar air pre-heat system was included on one project. This technology involves adding a heat absorbing medium that preheats incoming ventilation air, reducing the heating demand for ventilation air. This ERM was paired with a rooftop PV system, using the heat absorbing medium to draw heat away from the PV system. This provides an additional benefit of reducing the cell temperature of the PV panels, prolonging their expected service lives.

\section{Vertical Axis Wind Turbine}

Wind turbines use wind power to generate electricity. The amount of power generated depends on the speed and direction of the wind, therefor big wind turbines are equipped with motors that control the yaw and pitch of the blades. The size and profile of the blades also affect the amount of power generated.

\section{Combined Heat and Power with Biogas}

Combined heat and power 'cogeneration' technology uses a natural gas feed fuel to generate electricity, while also recovering and using the waste heat from combustion. A typical generator can achieve efficiency of $32 \%$ electric and $40 \%$ thermal generation.

This ERM was recommended on project 10, located in Alberta. As the greenhouse gas intensity of Alberta's electric grid is more than four times higher than that of combusted natural gas, switching to a natural-gas fired electricity resulted in carbon emission reductions.

\section{Results}

By utilizing the above conventional and innovative or emerging retrofit measures, the simulated buildings were 
able to achieve the annual carbon emissions listed in Table 5. These reduced emission levels represent implementing all available and technically feasible measures, realizing the maximum site potential for carbon reductions. A zero value indicates a carbon-neutral retrofit was achieved, while a negative value indicates a carbonpositive retrofit solution was achieved through excess generation of renewable energy exported to the local grid.

Table 5: Maximum carbon reduction results by building.

\begin{tabular}{|c|c|c|}
\hline $\begin{array}{c}\text { Building } \\
\text { Number }\end{array}$ & $\begin{array}{c}\text { Calibrated } \\
\text { Simulation: } \\
\text { tonsCO2eq/year } \\
\text { emitted }\end{array}$ & $\begin{array}{c}\text { Carbon Retrofit } \\
\text { Simulation: } \\
\text { tonsCO2eq } / \text { year } \\
\text { emitted }\end{array}$ \\
\hline 1 & 11,169 & 0 \\
\hline 2 & 12,192 & -1 \\
\hline 3 & 11,507 & -1 \\
\hline 4 & 19,488 & 624 \\
\hline 5 & 11,787 & -2 \\
\hline 6 & 14,244 & 0 \\
\hline 7 & 14,563 & 0 \\
\hline 8 & 1,061 & -22 \\
\hline 9 & 2,902 & -133 \\
\hline 10 & 6,013 & 0 \\
\hline
\end{tabular}

While simulated, technically possible, and presented to the building owners, it should be noted that economic constraints would likely prevent all retrofit measures from being implemented. As a marker of economic feasibility, the net-present value of each of these options was calculated and presented to the building owners. In each case, the analysis yielded a significantly negative net present value over a 25-year period. This is due largely to low costs of energy and carbon emissions relative to high capital costs to implement retrofit measures. To align with the Government of Canada (2016) Pan Canadian Pricing on Carbon Pollution plan, cost of carbon emissions was calculated at $\$ 10 /$ ton $\mathrm{CO}_{2 \text { eq }}$ at Year 1 , increasing evenly to $\$ 50 /$ tonCO $_{2 \mathrm{eq}}$ at Year 5. Per requirements of the client, the following escalation rates were used in the analysis:

- Carbon emission costs: $2.0 \%$ per year

- Energy costs: $2.0 \%$ per year

- Construction and capital costs: $2.5 \%$ per year

- Operations and maintenance costs: $1.90 \%$ per year

- Discount rate: $2.53 \%$

Table 6 lists the net present value of each of the maximum carbon reduction options. Net present value provides an indication of cost to upgrade and operate the new bundle of measures to achieve maximum carbon reduction relative to the baseline. Positive NPV indicates a savings relative to the baseline over 25 years, and conversely a negative NPV indicates a cost premium relative to the baseline. For the purposes of this study, the baseline is represented by the business-as-usual existing building scenario with upgrades only for equipment and material lifespan replacement.
Table 6: Net Present Value for Maximum Carbon Reduction Retrofit over 25 years.

\begin{tabular}{|c|c|}
\hline $\begin{array}{c}\text { Building } \\
\text { Number }\end{array}$ & Net Present Value \\
\hline 1 & $-\$ 12,505,325$ \\
\hline 2 & $-\$ 8,515,710$ \\
\hline 3 & $-\$ 5,824,023$ \\
\hline 4 & $-\$ 9,600,045$ \\
\hline 5 & $-\$ 13,093,542$ \\
\hline 6 & $-\$ 4,213,871$ \\
\hline 7 & $-\$ 2,130,737$ \\
\hline 8 & $-\$ 3,048,046$ \\
\hline 9 & $-\$ 8,644,355$ \\
\hline 10 & $-\$ 47,459,970$ \\
\hline
\end{tabular}

\section{Resultant Proportion of Retrofit Budget Directed to Emerging Technologies}

Building performance analysts looking to recommend emission reduction measures for deep carbon retrofits should be interested in the relative weighting of conventional carbon reduction measures versus emerging or innovative technologies. In particular, building owners will look to the analyst to provide a reasonable breakdown of cost. Table 7 lists the total retrofit cost on a per area basis with the percentage of that cost recommended to be directed to innovative and emerging measures to achieve simulated maximum carbon reduction. Also listed is the relative percentage of carbon reduction provided by the emerging and innovative technologies simulated in each of the maximum carbon reduction options. The remaining contribution is made up of savings from conventional envelope, HVAC, controls, and lighting measures.

\section{Table 7: Summary of Projects Analysed.}

\begin{tabular}{|c|c|c|c|}
\hline Building & $\begin{array}{c}\text { Total } \\
\text { Required } \\
\text { Retrofit } \\
\text { Cost, } \\
\mathbf{\text { CAD/m}} \mathbf{2}\end{array}$ & $\begin{array}{c}\text { Percentage of } \\
\text { cost Directed } \\
\text { to Innovative } \\
\text { and Emerging } \\
\text { Measures }\end{array}$ & $\begin{array}{c}\text { Percentage } \\
\text { of Carbon } \\
\text { Reduction } \\
\text { Provided by } \\
\text { Emerging } \\
\text { Technologies }\end{array}$ \\
\hline 1 & $\$ 1,792$ & $59 \%$ & $29 \%$ \\
\hline 2 & $\$ 2,463$ & $28 \%$ & $95 \%$ \\
\hline 3 & $\$ 2,758$ & $46 \%$ & $72 \%$ \\
\hline 4 & $\$ 1,734$ & $64 \%$ & $76 \%$ \\
\hline 5 & $\$ 1,791$ & $96 \%$ & $94 \%$ \\
\hline 6 & $\$ 789$ & $79 \%$ & $53 \%$ \\
\hline 7 & $\$ 2,213$ & $39 \%$ & $46 \%$ \\
\hline 8 & $\$ 934$ & $53 \%$ & $81 \%$ \\
\hline 9 & $\$ 811$ & $21 \%$ & $67 \%$ \\
\hline 10 & $\$ 1,852$ & $70 \%$ & $75 \%$ \\
\hline
\end{tabular}

Figure 1 shows the percentage of cost directed to innovative and emerging measures graphically. 


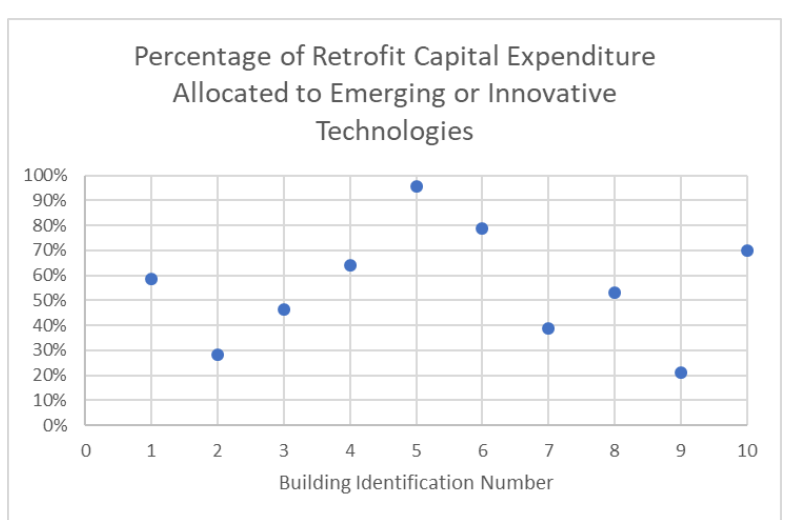

Figure 1: Percentage of Retrofit Cost for Innovative and Emerging Measures.

On average, to reach maximum site carbon reduction potential, the percentage of recommended retrofit budget to be allocated for emerging or innovative technology was observed to be $56 \%$ across the ten simulated projects.

Table 8 lists the emerging and innovative technologies simulated in each of the maximum carbon reduction options.

Table 8: Technologies simulated to reach maximum carbon reductions at each existing building.

\begin{tabular}{|c|c|}
\hline $\begin{array}{l}\text { Building } \\
\text { Number }\end{array}$ & $\begin{array}{l}\text { Emerging Technologies Included in } \\
\text { Maximum Carbon Retrofit Bundle }\end{array}$ \\
\hline 1 & $\begin{array}{c}\text { Seawater heat exchanger, } 135 \mathrm{~kW} \text { solar PV, } \\
885 \mathrm{~kW} \text { small scale tidal turbine, batteries } \\
\text { for off-grid storage }\end{array}$ \\
\hline 2 & $\begin{array}{c}\text { Ground-source heat exchanger, solar } \\
\text { domestic hot water, } 621 \mathrm{~kW} \text { solar PV, } \\
\text { batteries for off-grid storage }\end{array}$ \\
\hline 3 & $\begin{array}{l}\text { Ground-source heat exchanger, } 680 \mathrm{~kW} \\
\text { solar PV, batteries for off-grid storage }\end{array}$ \\
\hline 4 & $\begin{array}{l}\text { Ground-source heat exchanger, } 1137 \mathrm{~kW} \\
\text { solar PV, batteries for off-grid storage }\end{array}$ \\
\hline 5 & $\begin{array}{l}\text { Ground-source heat exchanger, } 1769 \mathrm{~kW} \\
\text { solar PV, batteries for off-grid storage }\end{array}$ \\
\hline 6 & $\begin{array}{l}\text { Ground-source heat exchanger, } 430 \mathrm{~kW} \\
\text { solar PV, } 103 \mathrm{~kW} \text { vertical axis wind- } \\
\text { turbines, batteries for off-grid storage }\end{array}$ \\
\hline 7 & $\begin{array}{l}\text { Ground-source heat exchanger, } 224 \mathrm{~kW} \\
\text { solar PV, batteries for off-grid storage }\end{array}$ \\
\hline 8 & $\begin{array}{l}\text { Ground-source heat exchanger, } 1,753 \mathrm{~kW} \\
\text { solar PV, batteries for off-grid storage }\end{array}$ \\
\hline 9 & $\begin{array}{l}\text { Ground-source heat exchanger, } 250 \mathrm{~kW} \\
\text { solar PV with solar air pre-heater, batteries } \\
\text { for off-grid storage }\end{array}$ \\
\hline 10 & $\begin{array}{l}\text { Combined heat and power generation with } \\
\text { carbon capture system, } 1,659 \mathrm{~kW} \text { solar PV }\end{array}$ \\
\hline
\end{tabular}

\section{Discussion -Emerging Technologies Not Included in Maximum Carbon Retrofit Bundles}

The following technologies were analysed for suitability but ultimately not recommended in the study. They may be more feasible as technology improves, costs reduce, or in locations with different climate, energy costs, or greenhouse gas intensity factors.

\section{Electrochromic Glazing}

Electrochromic glazing is able to vary its solar heat gain coefficient to maximize desired solar heat gain in winter, while minimizing undesired gains in summer. This is achieved by applying small amounts of electric current to an electrochromic film that has been applied to one of the window lites. Control can be manual or automatically scheduled through a BAS system.

This technology was not recommended at any of the ten simulated buildings. Based on modeling, energy and GHG emission savings were less than $2 \%$. This combined with the high cost of providing low voltage wiring to all glazing units made the ERM unfeasible. The advent of power over ethernet technologies may improve the economics of electrochromic glazing in the future.

\section{Double Skin Facade}

The double skin façade is based on the notion of exterior walls that respond dynamically to varying ambient conditions and that can incorporate a range of integrated sun-shading, natural ventilation, and thermal insulation devices or strategies. Double glass façades typically consist of two curtain walls with a space gap of $1 \mathrm{~m}$. The curtain wall requires operable windows plus needs to be vented at the top, include for interior catwalk, stairs, foundation, roof, structure. While this ERM was simulated to save roughly $7.2 \%$ and $10.5 \%$ on energy and GHG emissions, respectively, it was deemed unfeasible due to its high costs.

\section{Hydrogen Fuel Cell}

This analysis considered the inclusion of hydrogen fuel cells, specifically solid oxide fuel cell (SOFC) systems. Hydrogen fuel cells are packaged electrochemical systems that produce electricity by means of oxidizing a fuel, which in this case is natural gas, to produce electricity, with heat and water being byproducts.

Hydrogen fuel cells are not a renewable technology and are typically used are a cost savings measure as electricity is generally more costly than natural gas. Therefore, they are understood to be contradictory to the overall goal of achieving carbon neutrality at the sites analyzed and were not recommended.

\section{Phase Change Materials}

Phase change materials (PCMs) are materials that have properties allowing for thermal energy storage due to their ability to store and release latent heat. PCMs generally change from solid to liquid in order to store or release heat. When the ambient temperature is high, the PCMs will change into a liquid state to absorb the latent heat, whereas when the ambient temperature is low, the PCMs change into a solid state to release the heat gained in the liquid phase when the ambient temperature is higher.

However, PCMs do not actually conserve energy or reduce GHG emissions, their purpose is simply to reduce the peak space conditioning loads which can result in savings on electrical costs for customers billed for peak demand and/or time-of-use. Their lack of impact on carbon emissions and relevant cost data meant they were not recommended in the study. 


\section{Biomass (Wood Pellet) Boilers}

Biomass boilers were investigated but not recommended for implementation for carbon retrofits. The storage area to house wood pellets to heat the building for a week would be prohibitively large for most of the existing mechanical rooms. Additionally, the dimensions of each boiler are typically much larger than similarly sized natural gas and electric boilers. There are also several disadvantages such as the requirement for frequent maintenance.

\section{Sun Tracking Concentrated Solar PV Collector}

This ERM was not easily integrated retrofit projects as the energy and operational costs savings do not reflect better overall better usage of roof space when compared to standard roof- or ground-mounted solar PV.

\section{Solar PV Integrated Windows}

Solar panel integrated windows would represent an excellent opportunity to existing building retrofits looking to upgrade window performance and include on-site generation capacity. Unfortunately, this technology is currently not commercially available.

Some integrated systems do exist, however the opaque photovoltaic generating surface sits between two panes of glass, blocking light and views. Power blinds function similarly, embedding a generative strip on blinds sandwiched by glazing. At the time of the study, no solar PV integrated window products were deemed acceptable for implementation.

\section{Stirling Engine}

A Stirling engine is a heat engine that operates by cyclic compression and expansion of air or other gas at different temperatures. A key advantage of Stirling engines is their ability to take heat from a wide variety of sources and convert that heat into electricity. In terms of renewable sources of heat, this could include a solar reflecting array.

Based on unanswered requests indicating a lack of support from suppliers, solar integration with a Stirling engine was not recommended for implementation in the analysis.

\section{Algae Carbon Capture System}

The carbon sequestration system addressed is an algae photobioreactor (PBR) that captures GHG emissions onsite and converts them into algae-based biofuel. A PBR offers a controlled environment in a closed system to enable high productivity of algae (see Pond Technologies in Ontario). By generating algae, the $\mathrm{CO}_{2}$ in the atmosphere is captured and oxygen is generated, helping restore the atmospheric gas balance that's being upset using fossil fuels. The ratio of $\mathrm{CO}_{2}$-to-algae production is roughly 1.8 tons of $\mathrm{CO}_{2}$ to one ton of algae.

The technical feasibility of the algae carbon capture system depends on available conditioned space and constant loads to maintain $\mathrm{CO}_{2}$ feedstock. The economic feasibility of the system depends on the ability to sell produced algae as a revenue stream to offset annual cost of operations. Neither of these were deemed favourable for the ten buildings analysed.

\section{Conclusion}

To reach maximum site potential carbon reductions in existing buildings, capital investment in emerging and innovative technologies should be considered. Once conventional retrofit measures for reducing demand and improving efficiency have been simulated, building performance analysts should investigate opportunities for proven but innovative technologies such as solar photovoltaic, small scale tidal, battery storage systems, ground source heat exchange, solar air heaters, and combined heat and power systems. In some existing buildings and in locations with high emission factor electrical grids, these measures may prove more cost effective than traditional demand reduction measures.

The viability of other emerging technologies should be evaluated for suitability, as their relevance may increase in the coming years with improved technology and simulation capabilities. These measures include doubleskin facades, hydrogen fuel cells, phase change materials, sun-tracking concentrated solar PV collectors, solar PV integrated windows, Stirling engines, and carbon capture technologies.

This study focused on the reduction strategies for carbon emissions associated with the operation of existing buildings. Embodied carbon and energy were not considered in this analysis, however parallel studies on these topics are ongoing using a life-cycle analysis approach.

\section{Acknowledgements}

We thank our clients for their commitment to do what is best for the world and their trust in our team to see their vision to reality.

\section{References}

ASHRAE (2014). Guideline 14 Measurement of Energy, Demand, and Water Savings.

ASHRAE (2013). Ventilation for Acceptable Indoor Air Quality.

BOMA Canada. (2019). Building Definitions. Retrieved January $1, \quad 2019$ from http://bomacanada.ca/bomabest/resourcesupdates/bui ldingdefinitions/

Canada Green Building Council (2017). A Roadmap for Retrofits in Canada: Charting a path forward for large buildings. Ottawa (Canada).

Environment and Climate Change Canada (ECCC). (2016). Pan-Canadian Framework on Clean Growth and Climate Change. Gatineau (Canada).

Environment and Climate Change Canada (ECCC). (2018). National Inventory Report. Gatineau (Canada).

Government of Canada (2016). Pan-Canadian Pricing on Carbon Pollution. Retrieved October 1, 2018 from https://www.canada.ca/en/environment-climatechange/news/2016/10/canadian-approach-pricingcarbon-pollution.html 